\title{
化学発光検出法を用いた血圧調節におけるカテコールアミン代謝の役割解明
}

\author{
角田 誠
}

\section{Role of Catecholamine Metabolism in Blood Pressure Regulation Using Chemiluminescence Reaction Detection}

\author{
Makoto TSUNODA \\ Graduate School of Pharmaceutical Sciences, The University of Tokyo, \\ 7-3-1 Hongo, Bunkyo-ku, Tokyo 113-0033, Japan
}

(Received July 29, 2008)

\begin{abstract}
Catecholamines, namely, dopamine, norepinephrine and epinephrine, play important roles in higher animals as neurotransmitters or hormones, and are metabolized by catechol- $O$-methyltransferase (COMT). To elucidate the role of COMT in blood pressure regulation, we have developed simultaneous determination methods for catecholamines and their 3-O-methyl metabolites using high-performance liquid chromatography (HPLC)-peroxyoxalate chemiluminescence reaction detection. Using the developed method, we have found that inactivation of catecholamines by COMT is attenuated in hypertensive rats compared to normotensive rats. Furthermore, both the activities and the amounts of membrane-bound (MB-) COMT in the liver were found to be lower in hypertensive rats than in normotensive rats, which indicated that liver MB-COMT may be a relevant factor in blood pressure regulation.
\end{abstract}

Key words_ catecholamine; metanephrine; catechol- $O$-methyltransferase; chemiluminescence

\section{1. はじめに}

カテコールアミンは 3,4-ジヒドロキシフェニル骨 格を持つアミンの総称である. 生体内においてはノ ルエピネフリン（NE），エピネフリン（E），ドー パミン（DA）の 3 種が存在し, 神経伝達物質やホ ルモンとして重要な役割を果たしている. カテコー ルアミンの生体内濃度変動は, 合成, 神経終末から の放出，神経終末への再取り込み，代謝などにより 制御されている.

これまでの血圧調節におけるカテコールアミンの 役割に関する研究から，高血圧の成因としてカテ コールアミンが重要であると報告されているもの の，その代謝と血圧調節の関連を追求する研究はほ とんど報告されていない.カテコールアミンは, monoamine oxidase $と$ catechol- $O$-methyltransferase （COMT）の 2 つの酵素により代謝，不活性化され る. COMT は, カテコールアミンを含むカテコー

東京大学大学院薬学系研究科（于113-0033 東京都文京 区本郷 7-3-1)

e-mail: makotot@mol.f.u-tokyo.ac.jp

本総説は, 日本薬学会第 128 年会シンポジウム 16 で 発表したものを中心に記述したものである.
ル環を有する化合物のメ夕位の水酸基を $O$-メチル 化し，不活性化する酵素である。. ${ }^{1,2)}$ メチル供与体と して $S$-adenosyl-L-methionine（SAMe）を，活性化 因子として $\mathrm{Mg}^{2+}$ イオンを必要とする。 $\mathrm{NE}, \mathrm{E}$ 及び DA は，COMTにより，それぞれ，ノルメタネフ リン（NMN），メタネフリン（MN）及び 3-メトキ シチラミン（3-MT）に代謝される（Fig. 1)。われ われは，血圧調節におけるカテコールアミンの COMT によるメチル化代謝の役割を，ラットをモ デル動物として用い，カテコールアミンとそれらの 3-O-メチル代謝物の変動追跡により明らかにすべ く，研究を行った．本誌上シンポジウムでは，その 研究の一端を紹介する.

2. カテコールアミンとそれらの 3-O-メチル代謝 物の同時分析法の開発3)

血圧調節における個体レベルでのカテコールアミ

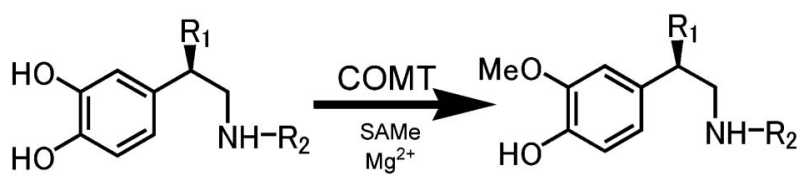

Fig. 1. Metabolic Pathway of Catecholamines by COMT 
ンのメチル化代謝の役割を把握するためには，血中 カテコールアミン及びそれらの 3-O-メチル代謝物 を同時に定量する必要があると考えた，そこで，は じめに，カテコールアミンとそれらの 3-O-メチル 代謝物の同時分析法の開発を試みた。

2-1. 分析法の高選択性 カテコールアミンと それらの3-O-メチル代謝物を同時に測定するため に，これまでに開発されていたカテコールアミン分 析法4,5)を適用することを考えた。

これまでに開発されていたカテコールアミン分析 法は，1）カテコールアミンを含むアミン類のみを 陽イオン交換カラムを用いて保持させることにより アミンに選択性をもたせる，2）エチレンジアミン がカテコール環と選択的に反応し蛍光物質を生成す ることを利用し，カテコール環に選択性を持たせる ことにより，カテコールアミンに対して高選択性を 持たせた方法である.

しかし，エチレンジアミンとの蛍光誘導体化反応 は，カテコール骨格に選択的であるため，3-O-メチ ル代謝物をそのまま反応させることはできない，

3-O-メチル代謝物は電気化学的酸化や化学的な酸化 により，o-キノン体に変換することが知られてい る。そこで，エチレンジアミンとの蛍光誘導体化の 前にオンラインでクーロメトリックな電気化学的酸 化を行うことにより，カテコールアミンだけでなく 3-O-メチル代謝物も検出することが可能になると考 えた (Fig. 2)。従来のカテコールアミン分析法の 分離カラムと蛍光誘導体化反応コイルの間に, クー ロメトリックな電気化学的酸化の可能なフローセル を組み込むことにより，カテコールアミンとそれら
の3-O-メチル代謝物の同時分析を実現した.

2-2. 分析法の高感度化 エチレンジアミン と, カテコールアミンとそれらの 3-O-メチル代謝 物の反応により生成する蛍光物質を，過シュウ酸エ ステル化学発光検出法6)を用いて検出することによ り，高感度化を試みた．過シュウ酸エステル化学発 光反応は, 塩基性触媒存在下, シュウ酸誘導体と過 酸化水素から生ずる活性中間体が蛍光物質との間に 電荷移動錯体を形成し，そのエネルギーを蛍光物質 に与えることにより蛍光物質を励起させ，これが元 の基底状態に戻る際に発光すると考えられている. 蛍光検出法が光源からの光エネルギーにより分子を 励起するのに対し，化学発光検出法では化学反応に より励起状態が生ずる. 光源に由来する散乱光や迷 光などのノイズの影響を抑えることができるため, 化学発光検出法は蛍光検出法に比べて高感度検出が 可能である。

2-3. 分析法の仕組み上述の高選択性と高感 度性を兼ね備えたカテコールアミンとそれらの 3-O-メチル代謝物の分析法を Fig. 3 にブロックダイ アグラムで示した。

サンプル注入から検出までを順を追って説明する.

（1）オートサンプラーより注入されたサンプル は，前処理試薬により前処理カラム（陽イオン交換 カラム）に導入され，カテコールアミンとそれらの 3-O-メチル代謝物を含むアミンのみが前処理カラム に吸着される。

（2）バルブを切り替え前処理力ラムに移動相を流 し，前処理カラムからカテコールアミンとそれらの 3-O-メチル代謝物を脱離させ, 分離カラム（ODS

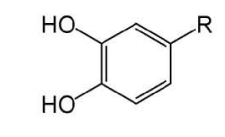

electrochemica

Catechol compounds

oxidation

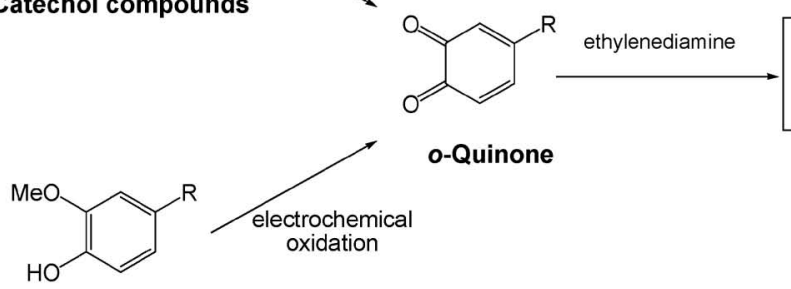

\section{Fluorescent $\longrightarrow$ Chemiluminescence}

derivatives $\mathrm{TDPO}_{\mathrm{H}} \mathrm{H}_{2} \mathrm{O}_{2}$ detection

4-Hydroxy-3-methoxyphenyl compounds

Fig. 2. Electrochemical Oxidation of Catechol and 4-Hydroxy-3-methoxyphenyl Compounds Followed by Ethylenediamine Reaction and Chemiluminescence Detection 


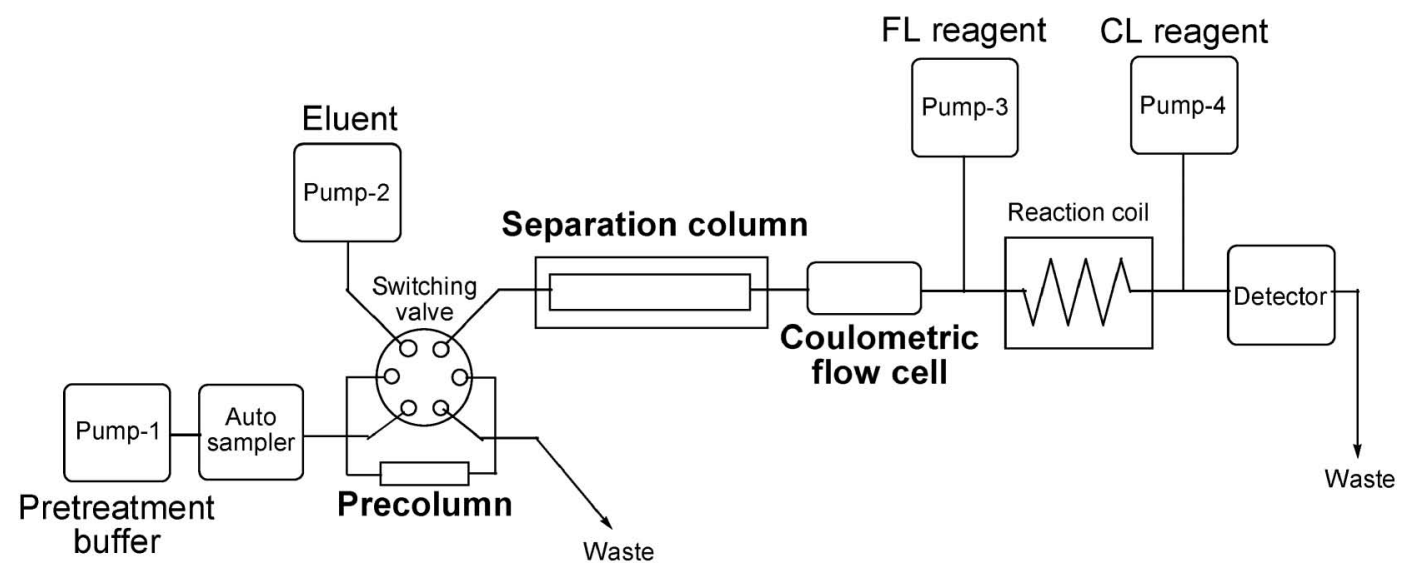

Fig. 3. Block Diagram for the Column-switching HPLC System for the Analysis of Catecholamines and Their 3-O-methyl Metabolites

カラム）にてカテコールアミンとそれらの 3-O-メ チル代謝物を分離する.

(3) 分離されたカテコールアミンとそれらの 3-O-メチル代謝物を電気化学的酸化により $o$-キノン 体に導く.

(4) o-キノン体とエチレンジアミンを反応コイル $\left(90^{\circ} \mathrm{C}, 10 \mathrm{~m}\right)$ 内で反応させ，蛍光物質に導く.

（5）最後に，シュウ酸エステルと過酸化水素を含 む化学発光試薬と，蛍光物質を混合させることによ り生ずる発光を化学発光検出器にて検出する.

2-4. クロマトグラムとバリデーション 内標 準として選択した 4-メトキシチラミン（4-MT） を 含めた 7 種化合物は, 60 分以内に十分な分離が達 成された [Fig. 4(a)]。ラット血漿 $50 \mu \mathrm{l}$ に適用し たところ， 3-MT を除く 5 種のカテコールアミン類 の定量が可能であった [Fig. 4(b)]．カテコールア ミン類の定量值は，それぞれ，NE: $1.05 \pm 0.03 ， \mathrm{E}$ : $0.64 \pm 0.02$, DA: $0.19 \pm 0.01, \mathrm{NMN}: 0.51 \pm 0.02, \mathrm{MN}$ : $0.26 \pm 0.01 \mathrm{pmol} / \mathrm{ml}$ (mean \pm S.E., $n=3$ ) であり, 文献值と同等であった。開発した分析法のバリデー ションを行った結果，検量線，精度，真度ともに良 好であった。検出限界は，3-10 fmol 程度であり， 従来の分析法7)に比べ, 10 倍以上高感度化が達成さ れた。必要な血漿量は， $50 \mu \mathrm{l}$ と従来の報告の $1 / 10$ 以下で済むことから，採血による生体への影響を最 小限に抑えることが可能になった。

3. 高血圧ラットと正常血圧ラットにおけるカテ コールアミンのメチル化代謝能の個体レベルでの 比較8)

生体の血圧調節機構の 1 つに，圧受容体反射があ (a)

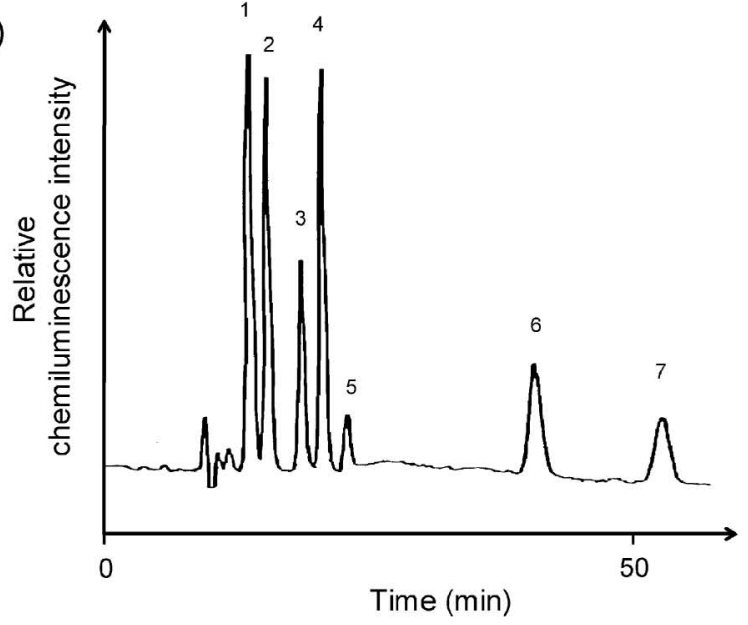

(b)

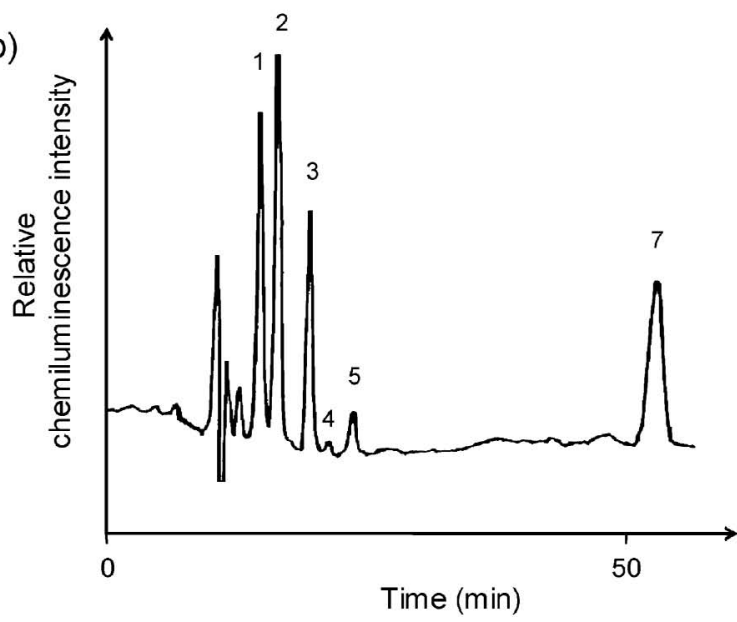

Fig. 4. Representative Chromatogram (a) of Standard Samples of Catecholamines and Their 3-O-methyl Metabolites (each $250 \mathrm{fmol}$ ) and (b) Obtained from Rat Plasma Sample $(45 \mu \mathrm{l})$ (IS).
Peaks; 1: NE, 2: E, 3: NMN, 4: DA, 5: MN, 6: 3-MT, and 7: 4-MT 
る，生体において血圧が降下すると，圧受容体がこ れを感知し，中枢へと信号が送られ，交感神経が活 性化し，血圧を上げる方向に働く。この圧受容体反 射の機能を，血圧調節における個体レベルでのカテ コールアミンのメチル化代謝能の評価に用いること にした．すなわち，ラットに降圧薬を投与すると， 血圧降下に対して，交感神経末端より NEが放出さ れ，放出された NEは，COMTの働きにより NMN に代謝，不活性化されるはずである。この血 中 $\mathrm{NE}$ 濃度と $\mathrm{NMN}$ 濃度の増加を上述の分析法で同 時に捉えることにした。

実際，ラットに $\mathrm{Ca}$ 拮抗薬を投与し段階的に血圧 を降下させたとき，血中 $\mathrm{NE}$ 濃度と $\mathrm{NMN}$ 濃度の上 昇がみられた。横軸に血中 NE 濃度, 縦軸に血中 NMN 濃度をプロットすると，両濃度には，良好な 直線性があり，その傾きは，個体レベルにおけるカ テコールアミンのメチル化代謝能を表していると考 えられた。

さらに，ヒトの本態性高血圧のモデルラットであ る高血圧自然発症ラット（SHR）とその対照であ る正常血圧（WKY）ラットにおけるこの変化を比 較することにより，血圧調節におけるカテコールア ミンのメチル化代謝を明らかにしようと考えた。 SHR と WKY ラットにおいて，この傾きを比較す ると，SHR の方が WKY ラットに比べて有意に小 さいことが明らかになった $(p<0.05)$ (Fig. 5)。こ のことから，SHRにおいて，個体レベルにおける カテコールアミンのメチル化代謝能が低下している ことが示唆された。

\section{4. カテコールアミンを基質とした COMT 活性} 測定法の開発9-13)

SHR における個体レベルでのカテコールアミン のメチル化代謝能低下が明らかになったことから， ぞの臓器における COMT 活性が低下しているのか を明らかにしようと考えた。これまでにCOMT 活 性測定法は, 数多く報告されているものの, dihydroxybenzoic acid（DBA）などの非生理的基質が多く 使われており，生体内におけるカテコールアミンの メチル化代謝を正しく捉えることが困難であると考 えられた，そこで，カテコールアミンを基質とした COMT 活性測定法を開発することにした。

COMT 活性は，基質から酵素反応により生成さ れるメチル代謝物を定量することにより測定され

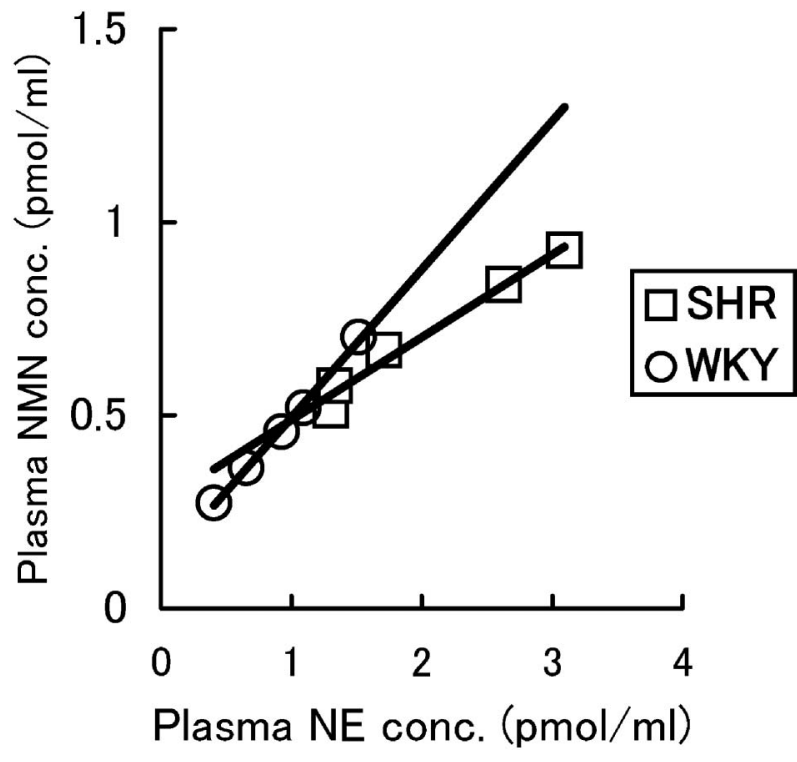

Fig. 5. Relationship between Plasma Norepinephrine (NE) and Normetanephrine (NMN) Concentration in the Face of an Acute Hypotension

る.すなわち，カテコールアミンを基質とすれば, それらの 3-O-メチル代謝物を定量することにより COMT 活性を測定することができる．上述のカテ コールアミンとそれらの 3-O-メチル代謝物の同時 分析法は，カテコールアミンとそれらの 3-O-メチ ル代謝物に選択性のある分析法であるため，カテ コールアミンを基質とした COMT 活性測定に応用 可能であると考えた.

COMT には, soluble (S) -COMT と membranebound (MB)-COMT の 2 つのアイソザイムが存在 する．そこで，ラット赤血球をサンプルとして用い， 2 つのアイソザイムについて最適条件の検討を行つ た。 NE を基質とし，酵素反応により生成したメチ ル代謝物 NMN を上述の分析法を用いて測定し た。酵素反応は，赤血球サンプルを超遠心分離によ り S-COMT 画分と MB-COMT 画分に分離し， そ

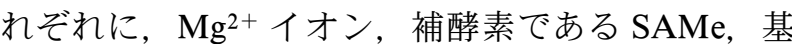
質として NE を加え， $37^{\circ} \mathrm{C}$ で行った。 S-COMT 画 分については, 反応生成物 NMN の蛍光検出での 測定が可能であった。しかし，MB-COMT 画分に ついては, 蛍光検出での $\mathrm{NMN}$ の定量が感度不足 により困難であり, 化学発光検出する必要があっ た．酵素反応条件については，至適 $\mathrm{pH}$ ，反応時間 の直線性, 酵素量の直線性を求め, 至適反応条件 下，酵素活性を算出した。同様に，E 及び DA を基 
質とした COMT 活性測定法を確立し，カテコール アミンの COMT に対する親和性を算出したところ, MB-COMT は，S-COMT よりも 20-60 倍ほど高い 親和性を示した。この結果は，カテコールアミンの メチル化代謝には，S-COMT よりも MB-COMT が 重要な役割を果たしていることを示唆するものであ ると考えられる。同時に，既報の方法により， DBA を基質としたときの親和性を算出したところ, S-COMT と MB-COMT に対する親和性は，ほぼ同 等であり，既報の方法ではカテコールアミンの代謝 を正しく反映しないものと考えられた。確立したカ テコールアミンを基質とした COMT 活性測定法 は，感度面においても既報の方法14)より優れてお り，生体内のカテコールアミンのメチル化代謝を調 ベるのに有用であると考えられた。

ラット肝臓，腎臓サンプルについても同様に酵素 反応条件の最適化を行い, カテコールアミンを基質 とした COMT 活性測定法を確立した.

5. SHR と WKY ラットにおける肝臓, 腎臓及 び赤血球中 COMT 活性と肝臓中 COMT タンパク 量の比較 ${ }^{15,16)}$

SHR におけるカテコールアミンのメチル化代謝 能低下の原因がどの臓器の COMT 活性に起因する のかを明らかにするために，上述の COMT 活性測 定法を用いて，SHR とWKY ラットにおける肝 臓，腎臓及び赤血球中 COMT 活性を測定した。そ の結果, 肝臓の MB-COMT 活性が, WKY ラット に比し，SHRにおいて低下していた。この結果よ り，肝臓に着目し，Western-blotting 法により， SHR と WKY ラットにおける COMT タンパク量の 比較を行ったところ，活性の結果と同様に，MBCOMT タンパク量が，SHRにおいて低下していた. SHR において WKY ラットと比べて S-COMT の夕 ンパク量が増加し，一方 MB-COMT は低下してい たこと，S-COMT とMB-COMT は同一遺伝子ょり 転写・翻訳され生成することから，転写・翻訳レベ ルにおいて，SHR では，なんらかの障害があるも のと考えられる.SHRにおける肝臓の MB-COMT 活性とタンパク量の低下は，個体レベルでの SHR におけるカテコールアミンのメチル化代謝能低下の 結果と一致しており，肝藏の MB-COMTが，循環 カテコールアミンの代謝に重要な役割を果たしてい ることを示唆するものである.

\section{6. おわりに}

HPLC-過シュウ酸エステル化学発光検出法を用 いたカテコールアミン代謝系の高感度同時分析法を 開発し，血圧降下時の血中カテコールアミンと代謝 系の変動を捉えることにより，SHRにおいて， WKY ラットに比し, カテコールアミンのメチル化 代謝能が低下していることを明らかにした。さら に，カテコールアミンを基質とした COMT 活性測 定法を開発し，検討したところ，SHRにおいて肝 臓の MB-COMT 活性が低下していることを明らか にした。また，SHRにおいて肝蔵の MB-COMT タ ンパク量も低下していた。この結果は, 肝臟の MB-COMT がカテコールアミンのメチル化代謝に おいて重要な役割を果たしていることを示唆するも のであった.

今後，ヒトにおける検討 ${ }^{17,18)}$ などにより，血圧調 節におけるカテコールアミンのメチル化代謝のさら なる役割解明が期待される。

謝辞本研究を遂行するに当たりご指導賜りま した東京大学名誉教授今井一洋先生に感謝申し上げ ます。また，ご助言，ご協力頂きました東京大学大 学院薬学系研究科教授船津高志先生をはじめ, 共同 研究者の方々に感謝申し上げます。

\section{REFERENCES}

1) Axelrod J., Tomchick R., J. Biol. Chem., 233, 702-705 (1958).

2) Männistö P., Kaakkola S., Pharmacol. Rev., 51, 593-628 (1999).

3) Tsunoda M., Takezawa K., Santa T., Imai K., Anal. Biochem., 269, 386-392 (1999).

4) Higashidate S., Imai K., Analyst, 117, 18631868 (1992).

5) Prados P., Higashidate S., Imai K., Biomed. Chromatogr., 8, 1-8 (1994).

6) Tsunoda M., Imai K., Anal. Chim. Acta, 541, 13-23 (2005).

7) Tsunoda M., Anal. Bioanal. Chem., 386, 506514 (2006).

8) Imai K., Tsunoda M., Takezawa K., Mitsuhashi K., Santa T., Nagashima K., Katayama K., Ohmori K., Proc. Jpn. Acad., 75B, 224227 (1999).

9) Tsunoda M., Takezawa K., Imai K., Analyst, 
126, 637-640 (2001).

10) Masuda M., Tsunoda M., Yusa Y., Yamada S., Imai K., Ann. Clin. Biochem., 39, 589-594 (2002).

11) Tsunoda M., Takezawa K., Masuda M., Imai K., Biomed. Chromatogr., 16, 536-541 (2002).

12) Masuda M., Tsunoda M., Imai K., Anal. Bioanal. Chem., 376, 1069-1073 (2003) .

13) Tsunoda M., Imai K., Anal. Bioanal. Chem., 380, 887-890 (2004).

14) Pihlavisto P., Reenila I., J. Chromatogr. B, 781, 359-372 (2002).
15) Tsunoda M., Tenhunen J., Tilgmann C., Arai H., Imai K., Hypertens. Res., 26, 923-927 (2003).

16) Masuda M., Tsunoda M., Imai K., Biol. Pharm. Bull., 26, 202-205 (2006) .

17) Tsunoda M., Nagayama M., Funatsu T., Hosoda S., Imai K., Clin. Chim. Acta, 366, 168-173 (2006).

18) Jordan J., Lipp A., Tank J., Schroder C., Stoffels M., Franke G., Diedrich A., Arnold G., Goldstein D. S., Sharma A. M., Luft F. C., Circulation, 106, 460-465 (2002). 